\title{
A Capability-Driven Turnaround Strategy for the Current Economic Environment
}

\author{
Booma Yandava
}

Babson-F. W. Olin Graduate School of Management $\bullet$ Wellesley Hills, MA

\section{Abstract}

Many Businesses were prompted to reevaluate their products and services as a result of the recent economic downturn. Changes were made to their business models to realign capabilities and performance in some cases. Businesses need to provide better products and faster services while faced with more discerning customers, emerging markets, and dynamic regulatory environments. In a turnaround situation, businesses need to reinvent strategies and position themselves to meet short-term goals, while functioning in a competitive landscape for the long-term. The capability-driven model leverages core business and operating capabilities to optimize the entire value chain; innovation and Corporate Social Responsibilities are integrated carefully for long-term sustainability. The proposed framework is based on careful studies of companies that returned to profitability from a failing situation.

\section{Introduction}

Businesses evolve all the time. However, the recent economic downturn (Survey of Current Business, 2009, 2010; IMF Sees Major Slowdown for Global Economy, Calls for Strong and Coordinated Policies to Support a Turnaround. October, 2008) accelerated this market dynamic and many businesses found themselves floundering for survival. Changes in customer behavior (Annual Retail Trade Report, 2008, 2009, 2010) and competitive pressures, along with blind spots that companies develop over time (dwindling profitability) stagnates revenue growth and loss of market capitalization (Consumer Trend Data, 2009-1010; Annual Retail Trade Report, 2008, 2009, 2010; and All Times Bankruptcy, P1995-2010). Companies once regarded highly in terms of shareholder value and market share fail to recognize changing market conditions; these firms need a strategy for turnaround. Several studies suggest numerous factors influencing turnaround including managerial changes, improvement in financial instruments, and tactical changes such as operational efficiency and competitive improvement (Barker \& Duhaime, 1997; Moulton, Thomas \& Pruett, 1996). These studies examine declining firms in the context of decline sources and organizations' responses to the decline (Barker \& Duhaime, 1997; 
Moulton, Thomas \& Pruett, 1996; Castrogiovanni \& Burton, 2000). It is argued that turnaround strategies are not applicable to all firms because most retrenchment activities are a consequence of decline and not a necessity to achieve turnaround (Barker \& Mone, 1994). Typical retrenchment activities are cost reduction and fixed asset reduction. The influence of typical retrenchment strategies in turnaround is understood poorly. Cost cutting measures are important, but an important question still remains unanswered, how to influence a declining firm toward turnaround other than adoption of a mere balance sheet approach?" This study examines the turnaround approaches of companies that did not file bankruptcy and took measures to address declining profitability.

Several companies, from various industries, fallen victim to market blindness were studied. These companies emerged stronger and with long-term viability, by implementing a holistic turnaround strategy. This study contributes to the emerging trend that suggests against the simplistic and standard approach to turnaround situations for companies in need of changing from non-profitability to profitability. This study reveals pertinent and repeating adaptable capabilities that every business in most industries can execute for long-term growth and profitability-at the heart of which is returning to core.

To formulate an adaptable strategic framework for successful turnaround in the wake of recent changes in economics and customer behaviors and preferences, a study to test the following research questions was conducted:

(1) Does sustainable turnaround require a holistic approach with a strong focus on core business capabilities?

(2) Is an effective operational strategy, with a coordinated approach, spanning the entire value chain of a business, more critical for a successful turnaround, rather than a finance focused approach?

Examining these research questions, a better understanding of factors that contribute to successful turnaround other than financial ones emerge.

This study reveals capabilities that many businesses can develop and adopt to emerge from declining profitability, for a long-term, sustained growth trajectory. The next section reviews some of the literature on corporate restructuring and turnaround. The precipitating factors leading to a turnaround situation are discussed. The following section discusses in detail the conceptual framework for a capabilitybased turnaround strategy. The approach for the study leading to the capability-based framework is delineated. Although several companies were studied and analyzed over two years, seven representative case study companies are discussed to illustrate specific propositions derived from the analysis: Kraft Foods Inc., Chiquita Brands 
International, Inc., The Talbots Inc., Apple Inc., Tyco Intl. Ltd., Blockbuster LLC, and Starbucks Corporation.

\section{Current Literature}

Turnaround studies are not new; there are several studies quoted in the management literature on various strategies with the purpose of enhancing a firm's chances of attaining sustainable recovery (Barker \& Duhaime, 1997; Barker \& Mone, 1994; Gilson, 1989). However, these studies are highly fragmented with primary emphases on a strong balance sheet and minimal attention given to business models that address competitive advantages (Hofer 1980; Hoffman, 1989; Vincent, Barker III, \& Duhaime, 1997; Lohrke \& Bedeian, 1998; Schendel, Patton, \& Riggs, 1976). Schendel et al. proposed that turnaround strategies can be classified under two categories: efficiency oriented and entrepreneurially oriented. In 1980, Hofer (1980) extended studies that addressed variability in achieving successful turnaround to include the original causes of a decline. He proposes that severity of decline dictates whether drastic cost cutting or operational improvements should be undertaken.

Operational efficiencies such as cost cutting and asset trimming are part of turning a company around, more so in economic downturns. It is interesting how firms take bold steps with entrepreneurial measures to position themselves, not just for short-term profitability but for long-term growth.. Many companies have recently cut costs by reallocating capital structures, shutting down manufacturing plants, reducing their workforce, or relocating to low-cost countries. Are businesses that cut costs effectively positioned for a turnaround? Only about one-third of companies intending to turn around their worsening condition do so; of these, only $40 \%$ to 50\% position themselves for long-term growth (All Times Bankruptcy., 1995-2010; Barker \& Duhaime, 1997; Schendel, Patton, \& Riggs, 1976).

Miller (1994) suggests that companies with great success either become prone to inertia (at inception or over time), immoderation, and inattention to changing market conditions. Several studies show that internal factors far outweigh external situations - directly or indirectly — as causes of failure. The predominant internal factor is failure to recognize deterioration. As pointed out by Miller and supported by this study, corporate cultures converge in few strategic ideals: do what works best and continue doing the same. It is easy to miss early warnings, which tend to be weak signals with elusive evidence. Upper management tends to not act or ignore early warning signs unless challenged by a crisis (Hoffman, 1989). There is a strong tendency to ignore preliminary data that signal 
business stagnation. Contributing to this is over-confidence and a reluctance to consult subordinates. Warning signs of a decline have historically been financial indicators such as decreased working capital and the inability to service short-term and long-term obligations. Factors such as changing customer behavior and increased competitive pressures are less measurable, though they are strong indicators. However, the most important indicators of how a company performs are observation and communication within the organization; $t$ few studies address these factors. Management must make a conscientious attempt to cultivate relationships across all levels of the organization.

Strategic choices made by managers in a declining corporate turnaround situation are a function of organizational ineptitude and management's perception of external factors (Tan \& See, 2004). More studies are warranted to further understand these factors. Turnaround approaches often face severe time limits, limited resources, and lack of stakeholders support (Vincent, Barker III, \& Duhaime 1997; Hitt \& Ireland 1985) that warrants a systematic approach; though levels of deterioration and resource constraints on strategic turnaround choices are not addressed. In 1998, Mone, McKinley, and Barker predicted that a firm responds either conservatively or innovatively as two ends of a spectrum, based on an organization's capacity constraints (Mone, McKinley, \& Barker 1998).

A literature review indicates that few studies address the sequence of actions that lead to successful recovery. When addressed, research focuses primarily on top management changes and firm-wide cost reduction through retrenchment. (Lohrke \& Bedeian, 1998; Schendel, Patton, \& Riggs, 1976). The current study offers a clear sequence of actions that can readily be adopted under most turnaround situations. Given the complex nature of turnarounds, this study is grounded by a few representative companies, from diverse industries, that positioned themselves for growth, because of turnaround strategies. The goal is to examine companies that had an appropriate amount of time to strategize turnaround approaches while facing declining performance.

For the purposes of this study, turnaround is defined as the recovery of a firm's performance following a consistent decline, with potential threat to its existence. The proposed framework is based on what worked. The criteria center on successful repositioning as assessed by z-score analysis (Altman, 1968), by applying a broad array of factors considering the entire turnaround process. Situations not leading to successful turnarounds are analyzed briefly. The proposed capability-driven framework is based on research and analysis. This framework includes seven pillars that enabled these companies to emerge from either, non-profitability or negative 
growth, to achieve real growth. They did so by recognizing the problem quickly and realigning capabilities, to address new demands in emerging markets. They integrated short-term profitability goals with operational execution. In the process, they redefined themselves as opportunity seekers, with the goal of optimizing operational performance. Along with efficiency measures, these organizations adopted entrepreneurial approaches to revising the business model, recognizing blind spots, paying attention to early warnings of deterioration, and enacting measures to create situational leaders among employees. They laid a solid foundation for long-term sustained growth, by integrating innovation and social responsibility, within the corporate culture.

\section{Precipitating Factors for Turnaround}

Various factors contribute to declining profitability. Turnaround requires a drastic change that produces significant achievement in growth and profitability in a short period, followed by long periods of sustained improvements. Although business failures more than quadrupled in recent years (2005 to 2009), many businesses are growing. Strategic planning for a stronger organization has become a key component of growth and traditional methods of turnaround strategies have often not yielded desired results. Analyzing the roots of failure, most result from Refusing to adapt to changing markets, poor execution of core business strategies, lack of longterm visions and poor governance structures, and the core removed too far from the current state. Although the balance sheet is an indicator of business failure, many companies face challenges beyond it. Identifying in advance key factors that underlie poorly performing balance sheets is a challenge. Firms also choose to implement a variety of ineffective turnaround methods, borne from improper diagnoses of causative agents that led to poor performance. The literature suggests various turnaround actions including organizational, financial, and operational. However, there is lack of comprehensive analyses of the various precipitating and industry competitive factor characteristics of the type of business.

\section{Situation Analysis of Selected Sample Cases}

Organizations generally have a set of capabilities that differentiates them and makes them successful in the market. After several years of successful growth, organizations are blind-sided by sudden changes in the environment such as increased competition; they become complacent after several years of growth. Going back to the core business model forces one to ask the question, "to whom do we offer value?" 
With unprecedented growth from 150 stores in 1992, to over 16,000 stores worldwide today, Starbucks is credited with converting a commodity into a premium. After more than a decade of steady growth, Starbucks did not expect to report losses. Some store sales declined in 2007 - the first time in the company's history. Its products were excessive in a time of recession and competitors offered coffee at much lower prices. In addition, Starbucks saw a steep increase in its capital expenditures due to declining real estate prices. Starbucks' core competency in gaining customer loyalty was in decline; the company needed to attract customers lured away by cost-effective coffee shops and rebuild customer loyalty.

Companies that grow too quickly, or grow with acquisitions over time, tend to be far removed from their core in comparison to companies that have organic growth strategies. It is challenging for organizations to take an objective look at existing competencies and determine how to differentiate themselves for longterm growth. For the companies we examined, there was no choice however long it took to get back to their core. Part of returning to core activities is also reigniting the entrepreneurial spirit among decision-makers and employees. Although Toyota is not one of the sample companies in this study, recent safety issues almost brought the company to its knees in rethinking its core business and threatened its seat at the top of the automobile industry (Kingston, February 2010). Focusing on unsustainable market share goals, Toyota took a risky approach and sacrificed its core competency, quality. Chasing market share as a primary goal, Toyota absorbed too much risk in the development of its products, which allowed quality issues to surface.

\section{Changes in Markets}

Sophisticated customers force executives to refocus their vision and internal capabilities to maintain differentiation. Along with customer demands, organizations need to adapt to changes in the global environment and meet increasing regulatory and environmental requirements. In 2001, Chiquita Brands filed for bankruptcy due to changes in market conditions, driven by trade tariffs in the European Union. Anticipating that the EU would open its borders to free trade, Chiquita invested heavily in infrastructure, incurring billions in debt. However, the EU imposed a quota system that favored imports from Africa and other countries over those from Latin America. This change in market conditions forced Chiquita's bankruptcy. New CEO, Cyrus Freidheim, implemented a commit and deliver strategy to focus on the core business of fresh fruit. 
Kraft was forced to rediscover its business and refocus its product portfolio to meet social demands as diet changes caused consumers switched from fat-based to organic and healthier food choices. Social changes caused declining revenues in $9 \%$ to $11 \%$ of companies (Annual Retail Trade Report., 2008, 2009, 2010). Technological changes force the retail industry to rediscover both online and brick-and-mortar presences to suit discerning customer needs.

\section{Operational Inefficiencies}

Operational edge is not considered a force in gaining a competitive edge for businesses. The strategic focus for profitability has largely been gaining market share or pricing advantage. However, changing technology, global outreach, discerning customers, and economic downturns forced businesses to recognize operational strategy as indispensable - a kind of trigger for greater competitive advantage in a global arena.

Operational inefficiencies were a factor in all companies studied. However, these companies recognized these inefficiencies and corrected them. Business process misalignments with the value chain and redundant manual processes led to inadequate use of resources. These, in turn, lead to operational inefficiencies that increased the risk of missing delivery targets and running operations at excessive costs. Operational efficiency gained by investments in technology or reengineered business processes allowed businesses to reinvent their models and deliver value to customers; we investigate this area further in subsequent sections.

\section{Failure to Adapt to Customer Needs}

Kraft Foods, which grew to a global company through acquisition, had a strong centralized management structure, combined with bureaucracy and misplaced decision-making. The company had difficulty keeping up with consumers' rapidly changing tastes, just as other big food companies did when commodity prices rose. Meanwhile, other private label brands and price pressure, from retailers such as Wal-Mart, led to declining market share in various divisions of Kraft around 2004. It missed earnings for several years. Kraft's lower margins, global scale, high diversification, and underleveraged balance sheet made it a good candidate for restructuring (Kraft - Annual Reports, 2003-2010). The restructuring efforts came with identification of troubles and cost-cutting measures along with organizational change from a highly centralized to a decentralized model when Irene Rosenfeld took over in 2006. Talbots Inc. failed to see changing taste in customer demographics. After years of 
growth and steady revenue, Talbots posted its yearly loss of \$189 million in 2007 (Talbots Inc. Annual Reports, 2006-2010). Customer research conducted by a new management team revealed that many customers, including middle-aged women, saw Talbot's merchandise as targeted to much older women; Talbots failed to engage with changing customer's lifestyle.

\section{Lack of Corporate Accountability}

A recent study suggested that violation of corporate governance - financial or non-financial - is as high as 9\% (Nini, Sufi, \& Smith, 2010). Such violations are followed by decreased investment spending, reduction in net debt issuance, and lower leverage and shareholder payouts. This forces managers to engage in riskier activities. It is interesting to note, that incidence of covenant violation as a repeat act, is far greater than first-time violations (Figure 1).

\section{Figure 1}

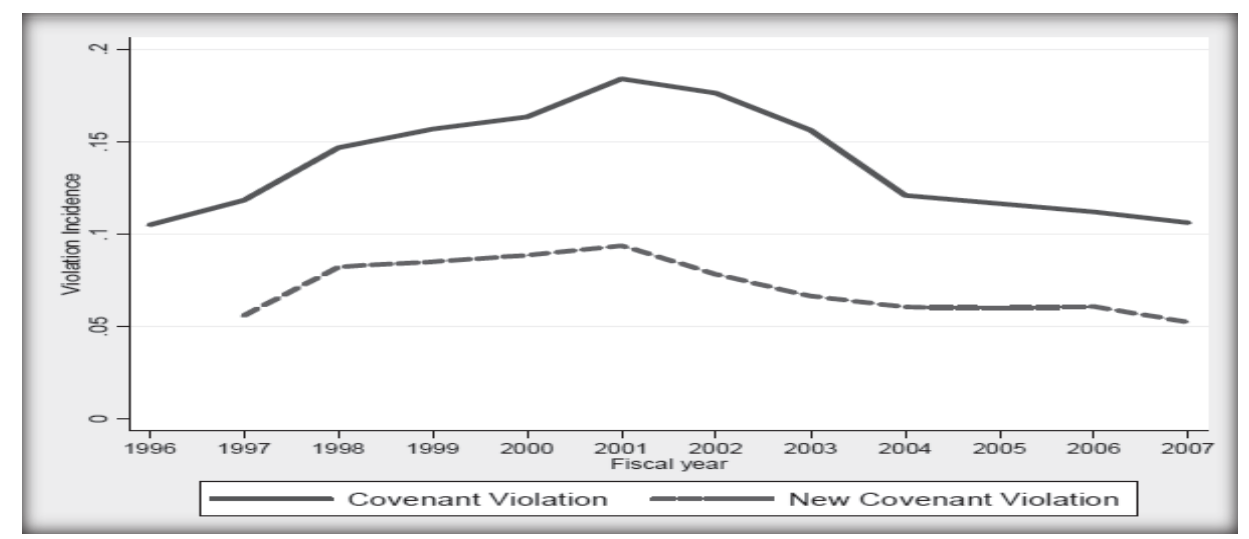

This figure represents the portion of firms that violated a financial covenant form 1996 to 2007. A new covenant violation is a financial violation by a firm that has not violated a covenant in the previous four quarters. This study included a sample of 8,666 firms. (Reproduced with permission)

Between the years 1990 to 2000 , Tyco made 1000 acquisitions at a minimum with no back-office support, business integration strategy, or operational support. Although Tyco's book value in 2001 exceeded $\$ 110$ billion, its long-term debt was over $\$ 30$ billion. In the middle of 2001, Tyco was embroiled in massive scandals and class action lawsuits from state Governments for defrauding shareholders. At 
the peak of its growth, with close to 260,000 employees and strong revenues, it became a symbol of runaway excess. With alleged debt-covenant violations and fraud charges against key executives, Tyco began massive restructurings. Corporate accountability and business ethics have been the sole cause of dwindling profitability in only a few cases. As companies take a more active role in Corporate Social Responsibility (CSR), corporate accountability has come to the center of public policies. C-level managers are monitored even more closely for conduct and violations.

\section{Proposed Capability-Driven Turnaround Model}

Demographic, social, and economic trends reshape consumer behaviors continually, which will become more substantial, dramatic, and global in the future. The companies examined, except Blockbuster Inc. went through the decline phase and recovered or are on a path to recovery. They showed a remarkable ability to respond to changing socioeconomic conditions. In light of current economic conditions, the traditional definition of a turnaround based on profitability alone is unrealistic. There is a time lag between improvement in competitiveness and subsequent profit improvement (Stopford \& Baden-Fuller, Jul 1990).

We examined several factors that contribute to decreasing profitability and the actions necessary for successful turnaround. Based on our analyses, we suggest a capability-driven business model that many companies in need of a turnaround can adopt. The capability-driven model is based on seven capabilities that allow organizations to emerge with stronger performance and market-driven capabilities Figure 2 includes a coherent set of interplays between strategy, operations, and tactics where a business can outperform, not only its existing status quo, but also its competition. At the heart of the model is aligning with the core of its business strongly, value for sustained growth.

Each set of capabilities is organized further under its own section, with a summary of the capabilities listed in Figures 5 through 10 respectively, under the Analysis and Discussion section. The summarized capabilities are the results of interviews with the companies under study. 


\section{Figure 2}

\section{Capability-Driven Turnaround Strategy}

\begin{tabular}{cc}
\hline \multicolumn{2}{c}{ Long-Term Shareholder Value } \\
\hline Innovation Capabilities & Sustainability \\
New Products/Services & Social Responsibility \\
Process Innovation & 'Serve the Society' Culture \\
\hline
\end{tabular}

Strategic

Capabilities

Operational

Capabilities
Return to 'Core' with Integrated Business Model

Value delivery to the best customers, partners

Centralized core processes

Efficient off shoring activities

Tight business integration; Quality of products/services

\begin{tabular}{cl}
\hline$\rightleftarrows$ Total Organizational Efficiency with Differentiated Capabilities $\longrightarrow$ \\
\hline Financial & Improved cost structures (near term liquidity) \\
Capabilities & Expanded revenue targets \\
& Efficient working capital management \\
Leadership & Leadership with strong delegation (path changer) \\
Capabilities & Instill culture of trust with greater emphasis on autonomy \\
& Strategic vision and flexibility convey sense of urgency \\
Organizational & Knowledge and skill based workforce; act as change harbingers \\
Capabilities & Performance and accountability based organizational DNA \\
& Commitment to organization
\end{tabular}

Clear Corporate Governance

Capability-driven framework

\section{Data Collection and Analysis}

In the corporate turnaround literature, multiple approaches including declining profitability (Robbins \& Pearce, 1992) and proximity of bankruptcy (Barker \& Duhaime, 1997) identify failing companies (Lohrke \& Bedeian, 1998). Initial analyses centered on identifying companies experiencing decreased profitability for at least two consecutive years, after consistent profitability and growth for several years in comparison to industry average. This sampling criterion is called the ++(plus, plus, minus) rule. The sample covers the period from 2001 to 2010, although data points were drawn from 2006 and 2010 due to relevancy. From an initial list of 245 companies, from 2000 companies from Standard \& Poor's (S\&P) database, we 
refined the target to those companies that did not file for bankruptcy, but experienced declining profitability and growth.

Initial data on the firms' restructuring activities and explanations were collected from Hoovers International, CapitalIQ (and other databases), annual and quarterly reports, Wall Street Journal - news and summaries, Extel Annual News, Standard and Poor's Compustat (SPC) Industrial Annual Research File of Companies, and other sources. From an initial identification of a random sample of 25 to 30 companies, we narrowed the list further to seven companies for in-depth analyses through interviews and follow up communication. The sample was stratified by considering only firms that indicated confidence in their performance, due to implementation of strategies for improvements discussed in this paper. The interview data was analyzed for text correlation using an Excel-based, text-mining approach.

Apple, Inc. served as a positive indicator for turning around its performance since 2001, where its net margin was close to $-0.7 \%$.

We depended on stakeholder opinion through interviews about the organization's strategies and implementation of improvement measures for hypothesis testing. This gave us a perspective of both financial and non-financial information about the business. Questions were open-ended, unstructured, and non-grouping to avert implicit bias in data collection. Analysis of the data yielded a set of repeated themes and patterns of analysis that were linked directly to an action on the ground scenario. We developed into a framework, a set of themes and patterns that can be applied, over several months, to turnaround situations.

\section{Results}

Analysis of existing literature indicates that Fitzpatrick (1931) was the first researcher to use ratio analysis as a comparative measure between failed and successful companies, although a significant relationship was not demonstrated. In 1966, Beaver (1966) used univariate analysis to predict business failure with no clear relationship. Altman (1968) expands on Beaver's work with multiple discriminate analyses in his seminal paper to predict business failures. Altman subsequently revised his model to incorporate a four-variable a-score prediction model. Currently, the z-score bankruptcy predictor is a widely accepted variable based on an algorithm proposed by Altman. The accepted cut-off criteria of z-score recommended and used in this study are as follows: 
- z-score 3.0 or above - Based on financial data, the firm is likely to emerge from a bankruptcy situation. There are other factors, such as management capabilities, that influence the company negatively.

- $\mathrm{z}$-score 2.7 to 3.0 - predicts company survival

- z-score 1.8 to 2.7 - predicts bankruptcy likely within two years

- z-score below 1.8 - predicts bankruptcy

For the purposes of our analyses, z-score was used only as a means to compare the health of companies before and after turnaround, along with other factors. In addition, a turnaround situation is considered when a firm encountered multiple years of declining financial performance metrics following a period of profitability within its industry, as observed from public databases (Bibeault, 1892; Hambrick \& Schecter, 1983)

Firms positioned for turnaround improved their operating performance substantially over post-recovery years, contributing to improvements in their z-score. The firms showed improvements in terms of Profit Margin, (PBIT/Sales), Return On Asset (ROA), and Cash Flow. The ash-flow measure also suggests positioning for long-term growth.

\section{Figure 3}

\section{Z-Score Analyses of Target Companies}

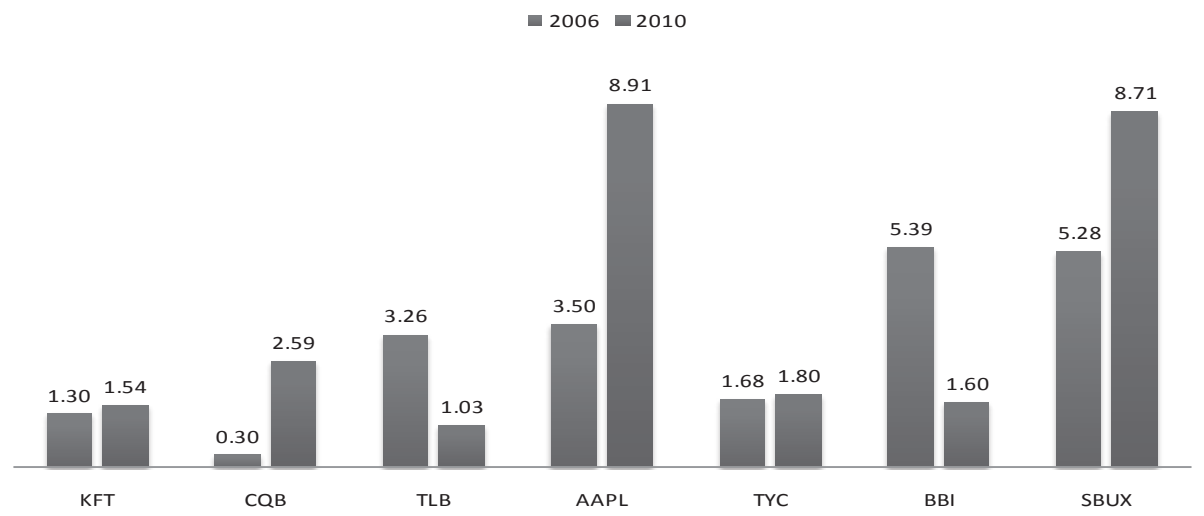

Z-score analyses of target companies during the analysis period. KFT: Kraft Foods Inc. CBQ: Chiquita Banana International; TLB: Talbots, Inc.; AAPL: Apple, Inc., BBI: Blockbuster, Inc., SBUX: Starbucks, Inc. 
Figure 3 shows the z-score analyses of our case study companies in the base and analysis years. Talbots and Blockbuster showed a decline in a-score while Chiquita International, Apple, Tyco International, and Kraft exhibited increases in z-score, indicative of returning to profitability. We also compared Return on Equity, Acid Test, and Current Ratios of the firms analyzed before and after turnaround (Figure 4). Acid Test and Current Ratios show improvements in the firms' ability to cover immediate liabilities without selling inventory. Although we included Blockbuster in our study for its revenue improvement, it remained unprofitable due to liquidity issues and intense competition. As predicted by our financial metrics and a-score analyses, Blockbuster filed for bankruptcy recently — examined further in the discussion section. Talbots showed improved revenue last quarter. We discuss Talbots in subsequent sections for its interesting turnaround approaches; although bankruptcy is predicted according to z-score analysis.

\section{Figure 4}

\section{Comparative analysis of ROE, Acid Test, and Current Ratios of the Target Companies}
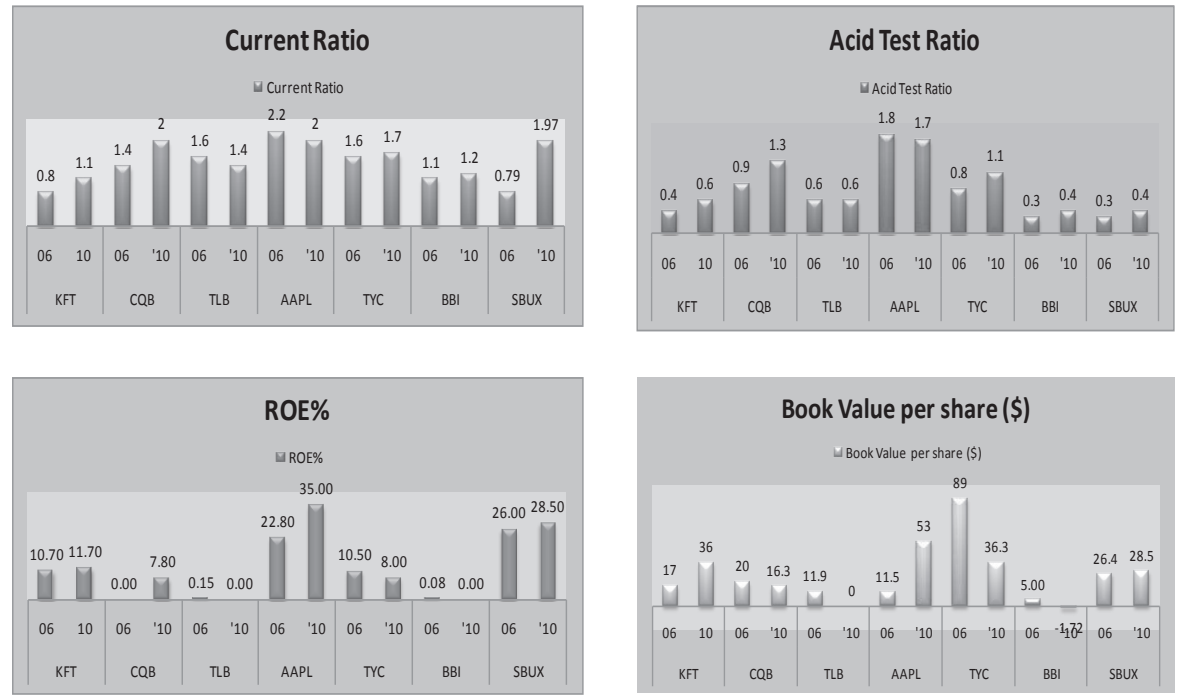

Current and Acid Test Ratios assess short-term profitability. ROE = Return on total equity: net income/average stockholders' equity. Acid Test Ratio also referred to as Quick ratio: (cash + marketable securities+ net receivables)/current liabilities; Current ratio = current assets/current liabilities. Book Value per share is included here only as a reference; not a significant contributor to this study due to rapid changes in book value because of the economic downturn. 
We further analyze interview data in terms of weighted average scores across various factors along the framework described in following sections. These factors support the initial hypothesis, that focusing on core business, is of paramount importance to returning to profitability in a turnaround situation. These firms had long-term operational strategies with investment in technology, research and development, and sustainability practices across the entire business for successful turnaround.

In the following sections, we discuss our analysis in terms of capabilities that emerged as a theme, a summary of which can be found in Tables 1, 2a, and 2b. We find that these firms assumed minimal alternatives in impacting change in various areas; although the time pattern and intensity varies slightly.

Table 1

\begin{tabular}{lcccc}
\hline Sample Firm & SIC Code & $\begin{array}{c}\text { Sample } \\
\text { Characteristics }\end{array}$ & $\begin{array}{c}\text { Bankruptcy } \\
\text { Declaration } \\
\text { (as of Yearend } \\
\text { - 2010) }\end{array}$ & $\begin{array}{c}\text { Asset } \\
\text { Reduction } \\
\text { + Cost } \\
\text { Reduction }\end{array}$ \\
\hline KFT Kraft Foods Inc.) & 20220000 & $\begin{array}{c}\text { Manufacturing; } \\
\text { Food Retail }\end{array}$ & No & Yes \\
$\begin{array}{l}\text { CQB (Chiquita } \\
\text { Brands Int'l. Inc.) }\end{array}$ & 01790000 & Manufacturing & No & Yes \\
TLB (The Talbots Inc.) & 56210000 & Retail & No & Yes \\
AAPL (Apple Inc.) & 36630000 & $\begin{array}{c}\text { Manufacturing } \\
\text { and Services }\end{array}$ & No & N/A \\
TYC (Tyco Intl. Ltd.) & 92240000 & Security Products & No & Yes \\
BBI (Blockbuster LLC) & N/A & Entertainment Retail & Yes & Yes \\
$\begin{array}{l}\text { SBUX (Starbucks } \\
\text { Corporation) }\end{array}$ & 58120000 & Specialty Eateries & No & Yes \\
\hline
\end{tabular}

Table 1: The industrial characteristic of the sample companies along with their bankruptcy status is defined. The companies studied underwent asset and cost reductions as a proactive measure influenced by economic downturn. Data are derived from public databases. 


\section{Table 2a}

\section{Sample}

Firm Recovery Observations

KFT Return to core, Operational restructuring, Firm wide reorganization with centralized core processes; Sr. Managers' performance and accountability

CQB Return to core(service excellence; fresh fruits focus); Capital expenditure (brand strengthening, innovation); business diversification from commodity to non-commodity; Leadership change with accountability and emphasis on sustainability

TLB Return to core; Operational restructuring (investment in technology), Capital restructuring, Reimage initiatives with emphasis on its core customers

AAPL Capital expenditure (Brand strengthening, innovation), return to core(innovation and product development) with open culture; Product development is tightly with all levels of workforce

TYC Return to core capabilities; Focus on lasting changes in value creation; Governance processes; standards of integrity, accountability and innovation; Managed communication to over communication

BBI Operational efficiencies; diversified capital intensive investments in partnerships and real estate; blind sighted by increased competition

SBUX Return to core (customer service; brand positioning); tight integrated business model with voice of the customer; quality of products and services

\section{Methodology Data Source}

Interviews with

Qualitative; experienced

Financial Stat. managers, analysis
Qualitative; Financial Stat. analysis

Qualitative; Financial Stat. analysis

Interviews with experienced managers, secondary sources

Interviews with experienced managers, secondary sources

Qualitative; Financial Stat. analysis

Interviews with experienced managers, secondary sources

Interviews with

Qualitative; experienced Financial Stat. analysis managers, secondary sources

Qualitative; Interviews with experienced managers, secondary sources; company archives

Qualitative; Interviews with Financial Stat. experienced analysis managers, secondary sources 
Table 2b

\section{Definitions of Terms Used in Table 2a}

\begin{tabular}{ll}
\hline Observed Variable & Definition \\
\hline Core Capabilities & $\begin{array}{l}\text { Core capabilities are defined as key business strengths the } \\
\text { organization has acquired that differentiate it from others. (Further } \\
\text { discussion on core under section - Strategic Capabilities) }\end{array}$ \\
Operational Restructuring & $\begin{array}{l}\text { Applying set of capabilities with a focus on improving business } \\
\text { efficiencies (refer to section for the operational capabilities } \\
\text { identified in this study: ) } \\
\text { Changes to the capital structure of a firm to achieve financial } \\
\text { Capital Restructuring }\end{array}$ \\
Value Creation & $\begin{array}{l}\text { Delivering what the end customers value. If customers value } \\
\text { quality of delivery, then the business processes, systems and } \\
\text { resources that produces the customer desired quality is highly } \\
\text { valuable to the organization } \\
\text { An organizational governance process requiring clear disclosure } \\
\text { of financial results and financial ownership }\end{array}$ \\
Voice of the Customer & Insights into customer preferences \\
Standards of Integrity & An organization's moral code
\end{tabular}

\section{Analysis and Discussion}

Academics and industries have long sought to identify the factors that allow companies to move from under-performance to over-performance. The case study approach with selected companies shows that these companies improved not only their balance sheets but also positioned themselves for long-term growth, even in the face of economic adversity. The companies we studied realized the fundamental need for transformation in several areas; they returned to their core, engaged employees, re-assessed global markets, and adapted to market conditions.

To provide clarity, we describe the proposed model first. The concept of reinventing the core is not new; Hamel and Prahalad (1990) proposed core capabilities as key to achieving competitive advantage. Rediscovering core values is easier said than done in a turnaround situation where the marketplace, company resources, company culture, management, products, and services change. Clever industry analysis builds customer focus and high product and service quality as differentiating factors. 
When Howard Schultz took over Starbucks again in 2008, he focused on improving its cost structure by taking operational measures such as labor cost reductions and eliminating unprofitable stores. He renewed customer focus as the core business model. With less reliance on revenues based on premium pricing and more focus on added customer value, Starbucks repositioned to offer service excellence along with brand strengthening and innovative service offerings.

Chiquita Brands repositioned to offer service excellence along with brand strengthening and innovative service offerings. Since its commodity distribution business was misaligned with its core, the company looked to divest this business unit. Similarly, other companies sought to integrate customer service with extended marketing strategies, technology, and real-time services as part of their core business.

Although Starbucks closed unprofitable stores, it launched free Wi-Fi services in others. By creating an Online Starbucks Community Network at www.mystarbucksidea.com, it invites customers to share their ideas and passion for coffee. Its loyalty card programs in the U.S. are popular. Talbots' strong synergy between its online store catalog and stores, with centralized inventory control mechanism and distribution system, offers great efficiency to managing sales. Talbots tried to move away from its core business - classic styles for women — into trendier styles. Apart from financial restructuring, it restructured operations to understand and cater to online customers more effectively. Realizing its home resides with loyal core customers, Talbots re-launched its website with new and more customer-focused product mix offerings, store segmentation, and loyalty programs. Talbots' major advantage has been strong consumer data, collected via proprietary credit card and loyalty programs and its ability to meld this information with sales, marketing, and customer service. By reducing its outstanding debt and stock repurchase program with the acquisition of BPW, Talbots achieved operating income close to $\$ 60$ million for 2010 , following two consecutive years of loss. With some liquidity in stock, Talbots is able to focus on long-term strategies such as enhanced marketing programs and improving store productivity.

Apple extended its core technology business into building its capabilities around a new industry - online music. It needed to reinvent its business from manufacturing and selling computers to integrating its online store music producers, vendors, and customers. Apple extended its core capability in technology to the web, building an online retail store for music; its innovation is pervasive, from products to process to impacting customer behavior.

In a recent study, Heracleous and Wirtz (2010) described how Singapore Airlines has both quality service and operational effectiveness through technology. Its 
core business is flying, yet it leverages not only software technology, but manufacturing process efficiency. For example, it ensures that fewer vehicle parts are used to reduce the risk of malfunction and high repair costs. Meeting customer needs means reaching out and understanding the customer mindset. Retailers have already begun to understand finer segmentation as a basis for a multi-banner model. Kraft realized that the local deli is a competitor and rebranded some of its own in line with local competition. Chiquita Brands introduced its Fresh Express salads and fruit bites in keeping with its core and customers focus. Internationally, it introduced fresh fruit smoothies in the Middle East.

Apple's repositioning of its consumer products business and its popular retail stores made it one of the most admired companies for innovation and design. Apple does not just meet customer needs; it transcends customer needs by creating markets for its products. For some companies, it is too soon to say whether they meet customer needs in terms of product portfolio, functionality and services. However, these companies have the right elements for a turnaround. Blockbuster rolled out several measures to prevent bankruptcy; at the time of this study, it could not return to profitability. Blockbuster's failure to discern changes in market dynamics and customers attitude was influential. It had difficulty improving margins in the face of competition, a shift in consumer behavior, and rapidly changing digital technology. Its rival companies, Apple and Netflix, embraced technology to deliver services and digital media cost-effectively. Blockbuster experienced several challenges integrating on-line delivery with its business model when it started adopting technology, in contrast to Apple which was able to integrate its business model with technology and customers seamlessly. Our findings revealed several factors that contributed to decreasing profitability and the actions necessary to turnaround business performance positively. Many companies in need of turnaround can adopt the capability-driven business framework (Figure 2). The model is based on seven capabilities that allow organizations to emerge with stronger performance and market-driven capabilities.

\section{Strategic Capabilities}

Strategic theorists predict that factors that sustain competitive advantage often generate long-term growth and performance. A firm's strategic capabilities offer companies competitive advantage, a distinguishing set of values that attract customers, employees, and investors. As stated by Zook (33), the right to win accrues to companies that stick to core business and find novel ways to use and exploit them. Companies with declining profits wandered from core capabilities by acquiring com- 
panies with minimal compatibilities contesting in unfamiliar markets or those simply having their lost core competencies. The companies studied here refocused their turnaround strategy on core capabilities and built other capabilities around them.

\section{Figure 5}

\section{Summary of Strategic Capabilities}

\section{Return to Core Capabilities \\ Emphasize strategy to grow and not slash \\ Investment in R \& D \\ Flexible and agile value-chain to meet customer demands}

Notes: Definition of Core Capabilities; for the purposes of this article, core capabilities are defined as key strengths an organization acquired that differentiate it from others, giving it an uncontested competitive advantage for long-term success. Core Capabilities relate to products and services. Core Capabilities are different from core values such as excellent customer service or emphasis on quality. Core values reflect what is important to an organization to compete on core capabilities. Core values underpin an organization's culture that excite, attract, and retain the work force, suppliers, and associated stakeholders.

After two years of reporting losses, Talbots refocused its core business on women in their 50s and above. In 2006, Talbots acquired J. Jill with the aim of catering to children and it started selling men's clothing. It soon realized that these products were unrelated to its existing core business. Its turnaround strategy, returning to its core capabilities, earned Talbots its right to win. The latest 10K statement (2011, 2nd quarter) from Talbots shows an operating income of $\$ 60$ million, as opposed to an operating loss of $\$ 11$ million in 2009.

Starbucks strategy to cut out breakfast and restore connections that customers have with the company's coffee was a successful return to core when Howard Schultz returned as CEO in early 2008. Successful turnaround was attributed to a series of investments in coffee-related products and offerings which were responsible for reigniting a coffee attachment with customers. Starbucks's latest financial statements indicate a successful turnaround, with reported profits for two subsequent years, and same-store increases of about $7 \%$ to $8 \%$ (Talbots Financial Statements 2009, 2010). Defining core business capabilities is critical for both short and longterm profitability because it further defines and influences other capabilities required for execution. 


\title{
Operational Capabilities
}

Turnaround companies realize they cannot recover competitive edge by adding market share alone or reducing product prices. There needs to be a concerted approach across the value chain, from customers, products, supplies, technology, and compliance from partners in bringing efficiency and operational strategic advantages. An efficient organizational capability leads to efficient integration across the entire value chain that, in turn, leads to operational excellence. Operational efficiency requires considerable investment in technology, but it offers not only automated business processes but far greater value from integrating businesses and processes. The result is a competitive advantage and an ability to differentiate by process innovation.

With its full range of systems across retail, finance, merchandising inventory distribution, and control, Talbots manages its inventory and customers in its online and brick and mortar stores. It succeeded in boosting sales from $28 \%$ to $46 \%$ in eight years with its loyalty card and credit card programs

Companies must try to cause minimal organizational disruptions when improving operation efficiencies; they should be part of a long-term turnaround strategy since it requires considerable thought, investment, and adaptation (Figure 8). Teams should align prioritized processes with strategic goals and quality improvements such as reducing non-conformance in a pharmaceutical manufacturing scenario.

\section{Figure 6}

Summary of Operational Capabilities

\author{
Automated business processes across key value chain for \\ improved efficiency \\ Strategic investment in key technologies \\ Achieve transformational process efficiency rather than continuous \\ improvement \\ Minimal organizational disruption while improving operational \\ efficiency \\ Strong focus on quality of products and services
}

Top manufacturers go further; they integrate and align core processes to increase transparency between manufacturing facilities and the customer. This leads to better management of processes and operations, and more process efficiencies with reduced cycle times and manufacturing costs. 


\section{Financial Capabilities}

Firms with successful turnarounds reduced debt to manage cost of capital. The key is to identify non-performing or underperforming business units or products and quickly find buyers. Sellers can use cash from liquidation to reduce debt or increase their cash balance. Well-managed companies always focus on cash and capital management. They cut down capital investments to the core. However, not all capital investments may be a non-priority. For example, one can take advantage of making an investment in real estate during an economic downturn. Companies in this study examined the factors listed in Figure 7 for successful restructuring, thereby improving debt-to-equity ratio. In addition, complete financial visibility and transparency led to improved decision-making and resource allocation.

Figure 7

Summary of Financial Capabilities

Disposing non-performing assets

Longer payment terms to suppliers

Restructure debt and equity structure

Swapping equity for debt (however painful it may be)

Assess opportunity to improve cash flow both in the short term and long term

Some companies have been especially innovative in their approach to capital restructuring. Despite a 40\% employee and 31\% inventory reduction and cost restructuring measures, Talbots experienced continued imbalance with enormous debt to its majority shareholder, Aeon. This Japanese retailer — Talbots' largest creditor — had an enormous liquidity problem even before the 2008 economic downturn. In a recent creative move, Talbots offered to merge with BPW Acquisitions, a special purpose acquisition company (SPAC) - a deal which offered enough funds to allow Talbots to retire existing debt. This bold and creative move also gave the retailer additional ability to secure capital from GE Capital.

\section{Transforming Leadership Capabilities}

Studies repeatedly shown that turning a company from a non-growth, low profitability, and possibly bankruptcy situation, to one of high growth and profitability, needs not only sound strategy, but clear and swift execution. Strong leaders who 
assemble a winning team with superb ability to delegate, communicate, coordinate, empower, and motivate staff are of paramount importance. In essence, the transformational leader should be a pathfinder with an ability to exploit the market-oriented uniqueness in key areas that directly supports the strategic direction.

When Tyco International was mired in scandal and Ed Breen was brought in to rescue the $\$ 38$ billion company with $\$ 30$ billion in debt, his first action was to communicate honestly and openly not only to shareholders, but to other external parties, such as the media, to rebuild trust and reputation. Today, Tyco is positioned for acquisition, using the same business model by which the company grew internationally (bolt-on acquisition strategy). Although Breen took other measures such as downsizing staff and adopting six sigma methodologies for operational efficiency and eliminating non-core businesses, he could rebuild trust only through strong communications. Tyco provided strong governance with accountability and sufficient autonomy in decision-making. In a recent transaction, Tyco acquired Brink's Home Security Holdings after almost nine years of strengthening its strategic focus on security platforms (Figure 8).

\section{Figure 8}

\section{Summary of Transformational Leadership Capabilities}

Strategy led by strongly committed senior executives

Focus on long term value creation

Integrated vision - with an ability to address all elements of organizational performance

Instill strong corporate entrepreneurial spirit

Create positive, dynamic environment for employees

Over communicate than under communicate

Manage change - as organizational DNA

Path finder

Create change implementer rather than change manager

\section{Organizational Capabilities}

Studies on organizational culture emphasize the importance of committed and motivated employees willing to support the corporate restructuring process. The entrepreneurial spirit of the team responsible for decision-making makes a signifi- 
cant difference. Division heads and top management do make strategic decisions, though employees should make autonomous and creative decision in executing a turnaround strategy.

Line managers should have profit and loss responsibilities with incentivized decision-making abilities. Hodak (2000) states that profit centers provide accountability. Combined with autonomy and operational decision-making, line managers and business unit heads are able to focus on process, efficiency, and profitability. Although this was apparent in most of the companies studied, Kraft, with its Organizing for Growth initiative, rewired the entire organization from being highly centralized to being highly decentralize in a span of three years.

In addition to autonomy, organizations should position themselves to operate in a cross-functional, cross-departmental culture. Far greater value is realized when team members are assembled across functions. A cross-functional team organization leads to cross-pollination of ideas and the ability to solve problems. However, cross-functional team should be assembled and dissolved in keeping with business demands. Cross-functional teams are supported by a flatter organizational structure because it fosters entrepreneurial abilities of knowledge workers. Knowledge and skills-based workforces act as change harbingers.

Building a cross-functional organization is difficult, demanding a highly interactive organizational culture, quick decision-making, and trust among employees. It is the responsibility of the management teams to create a positive, dynamic environment for employees, and functional skills are vital. Teamwork, character values, creative conflict resolution, and interactive openness are key skills that must be fostered through strong training and collaborative talent development models (Figure 9).

\section{Figure 9}

\section{Summary of Organizational Capabilities}

Integrated vision - with an ability to address all elements of organizational performance - skills, accountability, and employee commitment

Instill strong corporate entrepreneurial spirit

Create positive, dynamic environment for employees

Over communicate rather than under communicate

Manage change - as organizational DNA

Create change implementers rather than change managers 
An effective organizational capability to manage people should be aligned with competitive advantage; organizational capability is the engine under the turnaround vehicle. Managers and employees need to be aligned with business needs and focused employee roles and responsibilities.

\section{Sustainability and Corporate Social Responsibility (CSR)}

Sustainability is an imperative for any organization, but corporations define and adopt it differently. They look beyond shareholder value to add social value and environmental sustainability. Several studies have found a high correlation between financial performance and level of corporate social responsibility (CSR). In a turnaround situation, CSR takes a backseat. Companies need to detach themselves from the now attitude and look at CSR initiatives as a value-adding and sustained long-term goal. Sustainability initiatives lead to high investor confidence if done correctly. Common mistakes occur when companies assume too many sustainability initiatives or initiatives that do not align with strategic core competencies. Sustainability practices should extend to suppliers, contractors, and partners to have triple bottom-line impacts. Transparency and performance accountability should drive sustainability initiatives with improvements to the initial plan. As companies become more involved in CSR activities, they are monitored closely for public policy violations. A commitment to CSR itself is insufficient; appropriate corporate governance and business ethics should be in place. Along with making CSR an integral part of core business operations, strict standards of business conduct including provisions to avoid conflict of interest are necessary (Figure 10).

\section{Figure 10 \\ Summary of CSR Capabilities}

Sustainability and CSR initiatives should be in alignment with the core competencies

Should be part of the organizational DNA

An extended sustainability initialize that is applicable to suppliers, contractors, and partners in imperative

Be innovative

Be mindful that sustainability initiatives are not one-time but an on-going effort

Collaborate and continuously improve 


\section{Conclusion}

Extant literature and turnaround management professionals propose several avenues to identify factors that allow companies to return to profitability after a decline. In this paper, we focussed on proposing an adaptable framework by studying companies that showed marked improvement in performance after a decline in profitability. Although industry characteristics are important, the author observed that a holistic approach with firm-specific transformation capabilities is important (Figure 11). Rather than a focused attempt to continuous improvement, companies need a fundamental shift in the way they think about performance. This study suggests that clear understanding and focusing on well-defined their core capabilities lead to sustained profitable growth. Organizations studied in this paper refocused core business capabilities after experimenting with adjacent businesses, expanded core capabilities, or both (e.g., Starbucks). In the case of Blockbuster, the core business is renting videos, and renting videos online require a different set of operational capabilities than renting videos in retail stores. Key decisions were made such as hiring a retail chain CEO and making investments in video drop boxes without much attention to core business.

In a turnaround situation, returning to core ranges from investing in a management team that understands the core business, to defining core markets, suppliers, and core business models. Cost optimization measures should span entire corporate functions such as finance, technology services, procurement, accounting, and human resources. Cost centers should be transformed to be value centers by returning to core business models and values. This includes eliminating underperforming business units, strategic reallocation of capital, or even strategic long-term investment aligned with core business. Similarly, operational efficiency measures should span the entire key value-chain with a strong focus on quality. Operational excellence with strong emphasis on efficiency leads to financial results. For example, a customer management model must be based on partnership, rather than just another account. 


\section{Figure 11 \\ Transformation Capabilities}

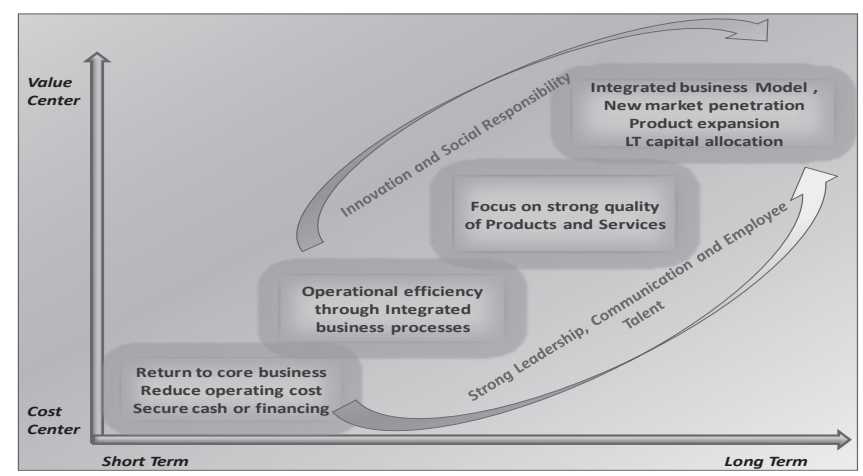

A fearless visionary leadership must provide a strong cultural framework for employees and motivate employees to achieve greater accountability and performance goals. Long-term strategic goals such as innovation and sustainability become the backbone of organizational transformation that leads and sustains the organization until market forces change again. Traditional approaches examine one or two aspects such as financial or operational improvements. These approaches are incremental and lacking in organizational perspective. Adapting a holistic approach transforms a cost center to a value center with strategically aligned, efficient business processes and strong customer value. Companies are challenged by external factors constantly. As shown by our case study firms, turnaround should be examined as organizational adaption to external changes; it is an opportunity to redefine standards of a competitive landscape. Although this study describes a capabilitydriven framework, a large industry-specific sample of companies would allow researchers to test the conceptual framework in a predictable context.

\section{Acknowledgement}

The author greatly acknowledges constant encouragement, help with research and critical readings of the manuscript by Prof. Peter Cohan - Professor of Business Strategy, Babson-Olin School of Management. The author also appreciates critical reading of the manuscript by Dr. Chandri Yandava - Broad Institute, MIT. 


\section{References}

Altman, E. (1968). Financial ratios, discriminant analysis and the prediction of corporate bankruptcy. Journal of Finance, 23(4), 589-609.

Baden-Fuller, C., \& Stopford, J. M. (1992). Rejuvenating the mature business: The competitive challenge. London: Routledge.

Barker, V, \& Duhaime, I. (1997). Strategic change in the turnaround companies: Theory. Strategic Management Journal, 18, 18-35.

Barker, V., \& Mone, M. (1994). Retrenchment: Cause of turnaround or consequence of decline? Strategic Management Journal, 15(5), 395-405.

Beaver, W. H. (1966). Financial ratios and predictors of failure. Empirical Research in Accounting, 4, 71-111.

Bibeault, D. B. (1892). Corporate turnaround. New York: McGraw Hill.

Bowman, E. D., \& Singh, H. (1993). Corporate restructuring: Reconfiguring the firm. Strategic Management Journal, 14, 5-14.

Castrogiovanni, G., \& Bruton, G. (2000). Business turnaround processes: Reconsidering. Journal of Business Research, 48, 25-34.

Fitzpatrick, P. J. (1931). Symptoms of industrial failures. Catholic University of.

Gilson, S. C. (1989). Management turnover and financial distress. Journal of Financial Economics, 25, 241-262.

Hambrick, D. C., \& Schecter, S. M. (1983). Turnaround strategies for mature industrial-product business units. Academy of Management Journal, 26(2), 231-248.

Heracleous, L., \& Wirtz, J. (2010). Singapore Airlines' balancing act - Asia's premier carrier successfully executes a dual strategy: It offers world-class service and is a cost leader. Harvard Business Review, 88(2010), 145-149.

Hitt, M. A., \& Ireland, R. D. (1985). Corporate distinctive competence, strategy. Strategic Management Journal, 6, 273-93.

Hodak, M. (2000). The viable EVA center (or how to slice a company so it doesn't bleed). Journal of Applied Corporate Finance, 13(3), 71-79.

Hofer, C. W. (1980). Turnaround strategies. Journal of Business Strategy, 1, 19-31.

Hoffman, R. C. (1989). Strategies for corporate turnaround: What do we know about them? Journal of General Management, 46, 46-66.

Kingston, J. (February, 2010). A crisis made in Japan. Retrieved March 2011, from online.wsj.com/article/SB10001424052748704533204575047370633234414. html

Lohrke, F. T., \& Bedeian, A. G. (DATE???). Managerial responses to declining performance. Advances in Applied, 5, 3-20. 
Miller, D. (1994). What happens after success: The perils of excellence. Journal of Management Studies, 31(3), 326-358.

Mone, M., McKinley, W., \& Barker, V. (1998). Organizational decline and innovation: A contingency framework. Academy of Management Review, 23(1), 115-322.

Moulton, W., Thomas, H., \& Pruett, M. (1996). Business failure pathways. Journal of Management, 22, 571-595.

Nini, G., Sufi, A., \& Smith, D. C. (November 2010). Creditor control rights, corporate governance, and firm value. Social Science Research Network.

Prahalad, C. K., \& Hamel, G. (1990). The core competence of the corporation. Harvard Business Review, 68(3).

Robbins, D. K., \& Pearce, J. A. (1992). Turnaround: Retrenchment and recovery. Strategic Management Journal, 13(4), 287-309.

Schendel, D., Patton, G. R., \& Riggs, J. (1976). Corporate turnaround strategies: A study of profit decline and recovery. Journal of General Management, Spring, 3-11.

Stopford, J. M., \& Baden-Fuller, C. (July 1990). Corporate rejuvenation. Journal of Management Studies, 27, 399-415.

Tan, H., \& See, H. (2004). Strategic reorientation and responses to the Asian financial crisis: The case of the manufacturing industry in Singapore. Asia Pacific Journal of Management, 21, 189-211.

Vincent, L., Barker III, A., \& Duhaime, I. M. (1997). Strategic change in turnaround firms: Theory and empirical evidence. Strategic Management Journal, 1, 13-38.

Zook, C., \& Allen, J. (2001, 2010). Profit from the core: A return to growth in turbulent times. Harvard Business Press.

Consumer Trend Data. (2009-1010). Retrieved Jan 2011, from www.nrf.com/modules.php?name $=$ Pages\&sp_id $=1419$

IMF Sees Major Slowdown for Global Economy, Calls for Strong and Coordinated Policies to Support a Turnaround. (October, 2008). Retrieved January 2010, from www.imf.org/external/np/sec/pr/2008/pr08236.htm

All Times Bankruptcy. (1995-2010). Retrieved January 2011, from www.bankruptcydata.com/researchcenter $2 . \mathrm{htm}$

Latest Annual Retail Trade Report. (2008, 2009, 2010). Retrieved Jan 2011, from www.census.gov/retail/\#arts

Survey of Current Business. (September 2010). Retrieved January 2011, from www. bea.gov/scb/index.htm 


\section{Biographical Sketch of Author}

Booma Yandava received her MBA from Babson - Olin Graduate School of Business. She is a certified global business professional, consulting and researching on a range of global business strategic and operational issues, including turnaround, operational improvement, and execution. This research work, started at Babson, is the result of an iterative process between collecting primary data, concept development and testing ideas. At present she is with KPMG. 